\title{
Neurogenic muscle hypertrophy
}

Figure Left calf findings
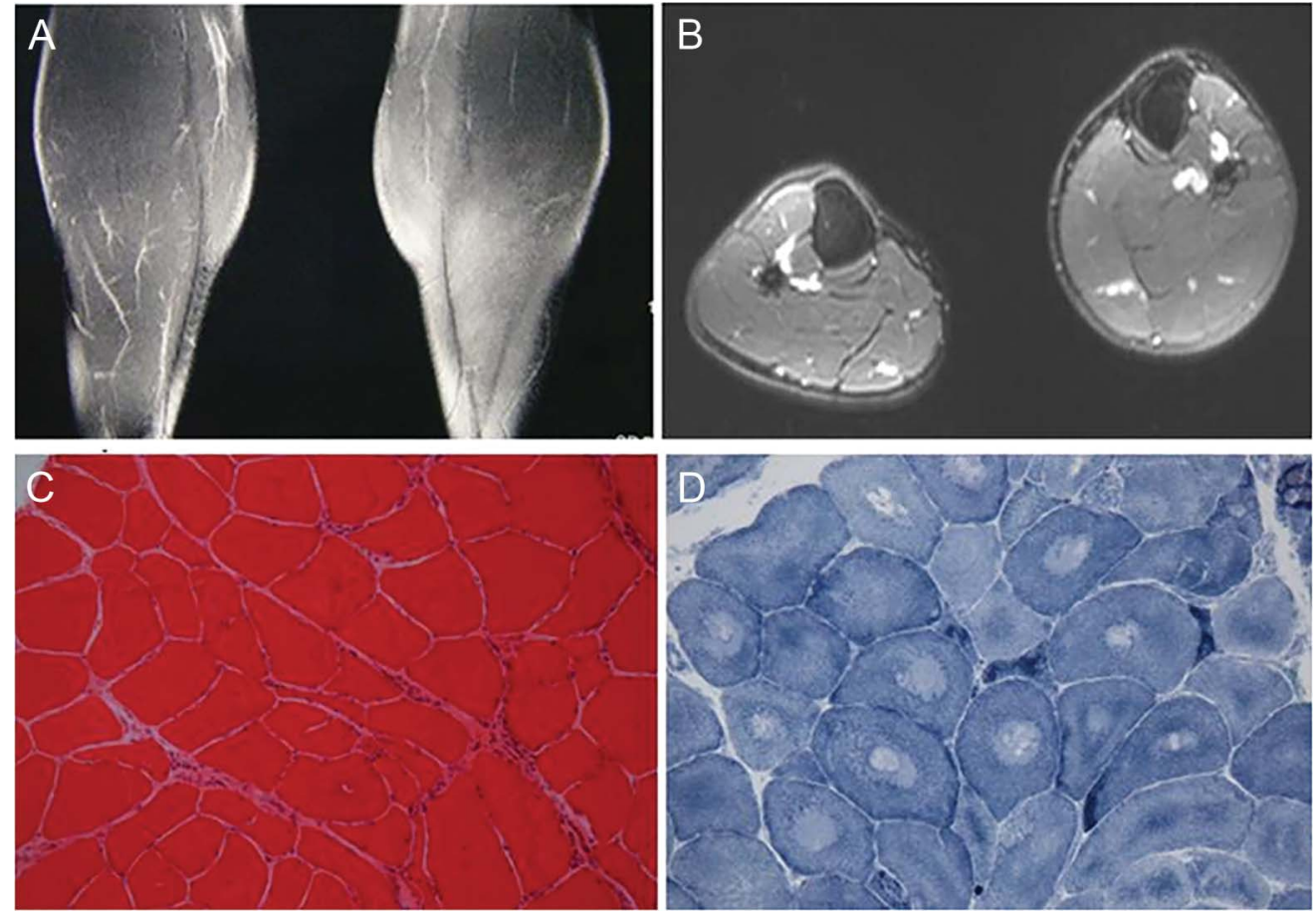

Coronal T2-weighted (A) and axial T2-weighted fat-saturated (B) MRI show diffuse swelling of gastrocnemius and soleus muscles. Gastrocnemius medialis biopsy: hematoxylin \& eosin $(\times 10)(C)$ and nicotinamide adenine dinucleotide tetrazolium reductase $(\times 20)(D)$ stains. Note variability in fiber diameters with predominance of hypertrophic fibers, internal nucleation, fiber splitting, disruption of intermyofibrillar architecture, and target fibers corresponding to denervation.

A 42-year-old man had a 2-year history of progressive asymptomatic left calf enlargement. MRI showed diffuse swelling of left calf muscles (figure, A and B); biopsy displayed neurogenic changes (figure, C and D). Electrodiagnostic examination results were compatible with left chronic S1 radiculopathy and lumbosacral MRI revealed an ipsilateral L5-S1 disc protrusion encroaching on the foraminal space.

Unilateral calf swelling may be associated with deep vein thrombosis, ruptured popliteal cyst, tumors, trauma, autoimmune disorders, vascular anomalies, focal myositis, and radiculopathy. Neurogenic disorders usually cause muscle atrophy; hypertrophic changes may result from compensatory work of nondenervated muscle fibers and spontaneous electrical activity of denervated muscle fibers. ${ }^{1}$

Simona Lattanzi, MD, Claudia Cagnetti, MD, Paolo Di Bella, MD, Marina Scarpelli, MD,

Leandro Provinciali, $M D$, Mauro Silvestrini, $M D$

From the Neurological Clinic, Department of Experimental and Clinical Medicine, Marche Polytechnic University, Ancona, Italy. Acknowledgment: The authors thank Dr. Francesco Sessa, Department of Neuroradiology, University Hospital of Ancona, Italy, for editing assistance.

Study funding: No targeted funding reported.

Disclosure: The authors report no disclosures relevant to the manuscript. Go to Neurology.org for full disclosures.

Correspondence to Dr. Lattanzi: alfierelattanzisimona@gmail.com

1. Zwick M, Teng L, Mu X, Springer JE, Davis BM. Overexpression of GDNF induces and maintains hyperinnervation of muscle fibers and multiple end-plate formation. Exp Neurol 2001;171:342-350. 


\title{
Neurology
}

\author{
Neurogenic muscle hypertrophy \\ Simona Lattanzi, Claudia Cagnetti, Paolo Di Bella, et al. \\ Neurology 2014;83;2191 \\ DOI 10.1212/WNL.0000000000001048
}

This information is current as of December 1, 2014

\section{Updated Information \&} Services

References

Subspecialty Collections

Permissions \& Licensing

Reprints including high resolution figures, can be found at: http://n.neurology.org/content/83/23/2191.full

This article cites 1 articles, 0 of which you can access for free at: http://n.neurology.org/content/83/23/2191.full\#ref-list-1

This article, along with others on similar topics, appears in the following collection(s):

All Clinical Neurology

http://n.neurology.org/cgi/collection/all_clinical_neurology

Clinical neurology examination

http://n.neurology.org/cgi/collection/clinical_neurology_examination

Information about reproducing this article in parts (figures,tables) or in its entirety can be found online at:

http://www.neurology.org/about/about_the_journal\#permissions

Information about ordering reprints can be found online:

http://n.neurology.org/subscribers/advertise

Neurology ${ }^{\circledR}$ is the official journal of the American Academy of Neurology. Published continuously since 1951, it is now a weekly with 48 issues per year. Copyright @ 2014 American Academy of Neurology. All rights reserved. Print ISSN: 0028-3878. Online ISSN: 1526-632X.

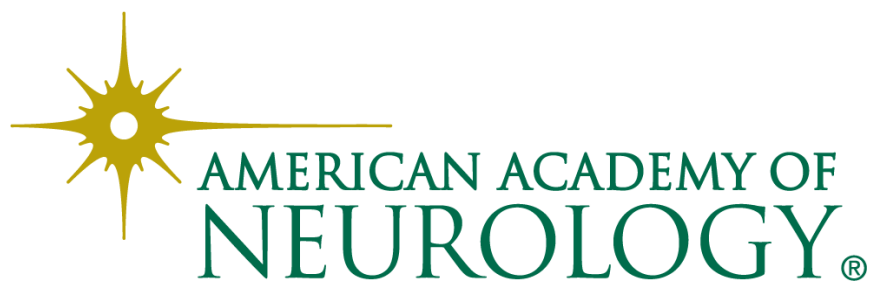

